\title{
MENGEMBANGKAN WIRAUSAHA DI PONDOK PESANTREN
}

\author{
Endang Sudarsih
}

\begin{abstract}
Abstrct
Socialization and development of entrepreneurship in Islamic Boarding School is vitally important. It will lighten the operational cost funding, and also improve the independence of boarding school. On the other hand, it will also train students' independency after graduate from the boarding school. This activity is designed to supply students in Pondok Pesantren At-Taufiq with a skill and effort in founding a business unit. The skill that is interested is computer, while the founded business is computer service. In Kecamatan Diwek and its surroundings, it is very rare to be found. The form of this vucer-activity is an entrepreneurship training program: service computer and computer network installation, and also making a business proposal. As continuation of training, it is delivered a set of computer as capital of forming a computer service business unit in Pondok Pesantren At-Taufiq. There are some constraints in execution of this program activity, such as human resources (SDM) in Pondok Pesantren that is lack of time and ability in permeating the knowledge. So that it is required more computer training for several times before computer service business unit could be actually realized and fulfill the activity purpose.
\end{abstract}

Keyword: pondok pesantren, santri, entrepreneurship, komputer

\section{PENDAHULUAN}

Pondok Pesantren merupakan lembaga pendidikan tertua di Indonesia (Prayitno, 2008) yang berfungsi sebagai pendidik sekaligus pembina kehidupan bermasyarakat, terutama di wilayah pedesaan. Pondok Pesantren sebagai pusat pendidikan agama bagi para santri, tetapi juga merupakan roda penggerak ekonomi bagi masyarakat sekitar. Hal ini terutama terjadi pada pondok-pondok pesantren yang hanya mengajar ilmu agama. Pada pondok pesantren jenis ini, semua biaya hidup dan pendidikan para santri ditanggung sepenuhnya oleh pemilik pondok. Budaya Pondok Pesantren yang menempatkan kyai pengasuh pondok sebagai sentral (panutan), menyebabkan pondok pesantren dituntut untuk memenuhi seluruh kebutuhan pondok tersebut.

Suramnya perekonomian yang melanda masyarakat dan tingginya tingkat pengangguran saat ini membuat banyak pondok pesantren yang mengalami kesulitan dalam memenuhi kebutuhan pondok dan santrinya. Masalah lain yang 
dihadapi adalah nasib para santri pasca 'nyantri' dari pondok pesantren. Lapangan kerja untuk mereka sangat kecil, apalagi jika mereka tidak mempunyai bekal pendidikan umum. Para santri pondok pesantren yang 'kelas menengah' ini sebagian besar berasal dari masyarakat sekitar, yang dari segi perekonomian banyak yang kurang mampu (miskin). Mahalnya biaya pendidikan menjadi alternatif terbaik bagi para orang tua untuk menitipkan anaknya ke pondok pesantren, sehingga tidak jarang biaya pendidikan pada akhirnya menjadi tanggungan pondok pesantren sepenuhnya. Mata pencaharian masyarakt sekitar adalah petani dan buruh tani. Beberapa permasalahan yang dihadapi oleh pondok pesantren modern (kelas menengah) dalam mempertahankan keberadaannya di tengah-tengah masyarakat adalah:

a. Tidak adanya unit usaha yang dapat diandalkan untuk memenuhi kebutuhan pondok.

b. Kondisi sosial ekonomi para santri yang lemah

c. Ketidaksiapan santri dalam memasuki dunia kerja pasca 'nyatri

d. Berkurangnya fungsi pesantren sebagai salah satu roda penggerak perekonomian bagi masyarakat sekitar.

Dengan mempertimbangkan permasalahan dan kondisi riil pondok pesantren, maka rumusan masalah dalam rangka pengabdian masyarakat ini adalah menghasilkan wirausaha baru (unit bisnis) dari Pondok Pesantren di bidang teknologi dan peningkatan skill (kemampuan dan ketrampilan) santri di bidang teknologi untuk bekal menjadi wirausaha baru. Diharapkan program pengabdian kepada masyarakat ini dapat memberi wawasan pada para santri di pondok pesantren tentang bidang-bidang usaha baru yang berbasis teknologi, yang dapat dijadikan ide dan dikembangkan untuk berwirausaha.

\section{METODE PELAKSANAAN}


Pengembangan wirausaha baru ini merupakan perpaduan antara pengembangan dan pelatihan kewirausahaan (workshop) yang ditujukan pada para santri di pondok pesantren yang ada di wilayah Kecamatan Diwek Jombang.

Rencananya kegiatan ini dibagi menjadi tiga aktivitas yaitu pembekalan (pelatihan), pembuatan proposal usaha dan praktek usaha. Rincian aktivitas tersebut adalah sebagai berikut:

\begin{tabular}{|c|l|l|c|c|}
\hline Nama & \multicolumn{1}{|c|}{$\begin{array}{c}\text { Bentuk } \\
\text { Aktivitas }\end{array}$} & \multicolumn{1}{|c|}{ Materi } & $\begin{array}{c}\text { Metode } \\
\text { Aktivitas }\end{array}$ & Waktu \\
\hline Aktivitas I & $\begin{array}{l}\text { Pembekalan } \\
\text { skill dan usaha } \\
\text { (dipilih 2 jenis } \\
\text { pelatihan) }\end{array}$ & $\begin{array}{l}\text { Servis computer } \\
\text { Service HP } \\
\text { Bengkel sepeda motor } \\
\text { Percetakan \& sablon } \\
\text { Seni bordir dengan komputer }\end{array}$ & Workshop & 2 hari \\
\hline $\begin{array}{c}\text { Aktivitas } \\
\text { II }\end{array}$ & $\begin{array}{l}\text { Penyusunan } \\
\text { Proposal usaha }\end{array}$ & $\begin{array}{l}\text { Produksi } \\
\text { Keuangan }\end{array}$ & Praktek & 1 hari \\
\hline $\begin{array}{c}\text { Aktivitas } \\
\text { III }\end{array}$ & $\begin{array}{l}\text { Membuat usaha } \\
\text { sesuai dengan } \\
\text { pelatihan yang } \\
\text { diikuti }\end{array}$ & $\begin{array}{l}\text { Memilih sesuai dengan } \\
\text { pilihan jenis usaha yang telah } \\
\text { dilaksanakan. }\end{array}$ & $\begin{array}{l}\text { Praktek } \\
\text { usaha }\end{array}$ & $\begin{array}{l}\text { Sampai } \\
\text { selesai }\end{array}$ \\
\hline
\end{tabular}

\section{Adapun tahap-tahap dalam pelaksanaan workshop ini adalah sebagai}

\section{berikut:}

1. Pendataan pondok pesantren yang ada di Kecamatan Diwek yang akan diikutserta dalam workshop.

2. Pendataan santri yang mengikuti workshop

3. Pendataan jenis usaha yang diinginkan oleh peserta pelatihan. Peserta pelatihan memilih jenis usaha yang telah ditentukan oleh panitia pelaksana. Workshop yang diadakan untuk satu jenis usaha dan diambil dari permintaan terbanyak.

4. Panitia menghubungi tenaga ahli pada jenis usaha yang diinginkan oleh peserta untuk memberikan workshop.

5. Pelaksanaan aktivitas/workshop.

6. Pelaksanaan aktivitas penyusunan proposal usaha.

7. Pengajuan proposal usaha oleh santri atau pondok pesantren peserta pelatihan. 
8. Pemilihan proposal usaha yang diajukan oleh santri atau pondok pesantrean.

9. Pelaksanaan/realisasi proposal usaha bagi masing-masing pondok pesantren.

10.Konsultasi dan evaluasi pelaksanaan proposal usaha

11.Penyusunan Laporan.

Dengan adanya transformasi teknologi dari perguruan tinggi ini, maka pondok pesantren akan melahirkan wirausaha - wirausaha baru yang berbasis teknologi. Dasar - dasar pembekalan teknologi ini juga akan dapat memacu sikap kreatif dan inovasi para santri menghadapi kendala - kendala yang dihadapi dalam membuka usaha (berwirausaha). Unit usaha pondok pesantren dan wirausaha wirausaha baru yang muncul dikalangan santri dan berbasis teknologi, akan meningkatkan kembali minat masyarakat terhadap pendidikan dan pengajaran di pondok pesantren sebagai alternatif pendidikan umum yang ada.

\section{A. Bentuk Kegiatan}

Kegiatan pengabdian pada masyarakat ini berbentuk pelatihan. Dari beberapa jenis pelatihan yang ditawarkan, yaitu: service HP, bengkel sepeda motor, percetakan \& sablon, seni bordir dengan komputer, ternyata yang diinginkan ada dua yaitu service HP dan service komputer dengan alasan:

1. Pondok Pesantren mendapat bantuan 3 unit komputer, tetapi SDM-nya tidak memadai.

2. Banyak Guru Madhrasah Ibtidaiyah, Madhrasah Tsanawiyah dan SMA Kejuruan yang berada di bawah naung Pondok Pesantren yang tidak paham komputer.

3. Siswa-siswa SMA Kejuruan banyak yang belum tahu dan paham tentang komputer.

4. Jasa service komputer dan HP hampir tidak ada di sekitar daerah tersebut.

5. HP dan Komputer mulai menjadi suatu kebutuhan yang berkembang di lokasi. 
Setelah dikaji ulang dan didiskusikan dengan pimpinan Pondok Pesantren At-Taufiq, serta calon peserta pelatihan, maka diputuskan bahwa pelatihan yang akan diberikan adalah usaha jasa service komputer dan jaringan komputer.

Ada beberapa perubahan yang dilakukan dalam pelaksanaan pengabdian kepada masyarakat ini dikarenakan:

1. Minimnya pengetahuan dan pemahaman peserta komputer dan jaringan

2. Banyak dan beragamnya peserta.

Untuk itu pelatihan kewirausahaan ini lebih fokus pada pembekalan ketrampilan dan pemahaman tentang komputer dan jaringan, sehingga memakan waktu 3 hari penuh. Aktivitas II, yaitu tata cara penyusunan proposal bisnis tetap diberikan, namun aktivitas ini tidak sampai pada tahap peserta menyusun proposal usaha.

Selanjutnya, dengan mempertimbangkan kemampuan dan asal instansi/institusi peserta yang mengikuti pelatihan, maka tim memutuskan untuk tidak melakukan kompetisi proposal usaha yang rencananya akan mendanai senilai Rp2.000.000,- bagi yang proposal usahanya memenuhi kriteria. Anggaran untuk kompetisi ini dialihrupakan dalam bentuk komputer beserta pelengkapan dan peralatannya, dan diserahkan pada Pondok Pesantren sebagai modal untuk mendirikan usaha service komputer dan jaringan. Usaha service komputer ini dikelola koperasi dan SMA Kejuruan di lingkungan Pondok Pesantren At-Taufiq.

\section{B. Peserta}

Rencana awal, peserta adalah para santri dari pondok pesantren - pondok pesantren yang ada di sekitar Bogem. Namun keterbatasan waktu dan tenaga, serta banyaknya santri dari Pondok Pesantren At-Taufiq yang berminat mengikuti pelatihan, maka diputuskan peserta adalah para santri dari Pondok Pesantren AtTaufiq saja. Peserta pelatihan usaha jasa service komputer dan jaringan komputer ini terdari dari guru, santri, dan lulusan SMK di Pondok Pesantren At-Taufiq Desa Bogem Kecamatan Diwek Kabupaten Jombang. 
Jumlah peserta yang rencananya hanya 20 orang, ternyata membengkak menjadi 35 orang. Panitia terpaksa menolak beberapa peserta dari pondok pesantren lain yang ingin mengikuti pelatihan kewirausahaan karena keterbatasan tempat dan waktu.

Jadwal kegiatan pelatihan (aktivitas I dan aktivitas II) yang rencana dilakukan pada bulan ke-empat bergeser menjadi bulan Juni, tepatnya pada hari Sabtu - Minggu tanggal 20 dan 21 Juni 2009. kegiatan ini dilaksanakan di salah satu gedung sekolah milik Yayasan At-Taufiq di Desa Bogem Kecamatan Diwek - Jombang.

\section{HASIL DAN PEMBAHASAN}

Berdasarkan hasil survey ke para santri dan pemilik Pondok Pesantren, maka kegiatan pelatihan dan unit usaha (bisnis) yang diinginkan adalah terbentuknya unit usaha service komputer. Unit usaha ini akan berada dalam naungan koperasi milik Pondok Pesantren At-Taufiq. Unit usaha ini rencananya akan oleh dikelola guru komputer (guru Yayasan Pondok Pesantren At-Taufiq) dan santri pondok yang mahir komputer.

\section{Kendala dan Tanggapan}

Sebagaimana yang telah diungkapkan diawal, bahwa dengan pelatihan ini diharapkan pengetahuan para santri tentang komputer bertambah dan kemandirian mereka terbentuk. Berdasarkan survey dan kajian di lapangan, menunjukkan bahwa tujuan membentuk wirausaha baru tersebut sulit tercapai dalam waktu singkat. Hal ini dikarenakan beberapa faktor, diantaranya adalah sebagai berikut:

1. Minimnya tingkat pengetahuan dan kemampuan peserta secara umum tentang komputer, baik dari segi pemanfaatan maupun peralatannya. Terutama para santri tinggal yang menjadi sasaran utama kegiatan ini.

2. Keterbatasan jumlah komputer dan perangkatnya yang bisa digunakan, baik untuk pelaksanaan pekerjaan maupun untuk latihan.

3. Komputer bukan merupakan kebutuhan utama para santri sehingga mereka tidak merasa perlu mengerti proses kerjanya, yang penting bisa mengetik. 
4. Kurangnya motivasi peserta/santri untuk menjadi wirausaha. Sebagian besar pingin bekerja atau jadi pegawai di pondok atau di kantor pemerintah lain.

Meskipun demikian, ada beberapa peserta/santri, yang memang sebelumnya sudah paham dan tertarik dengan bidang komputer yang ditengarai bisa mengembangkan usaha jasa service komputer. Namun demikian mereka ini masih membutuhkan pembinaan lebih intensif lagi. Ada juga peserta yang telah merintis usaha komputer dan mencoba berwirausaha. Peserta ini sangat antusias untuk dibimbing membuat proposal usaha. Untuk hal khusus semacam ini, tim membuka jasa konsultasi gratis.

Sebagai langkah perbaikan untuk mensukseskan program pembentukkan wirausaha baru di pondok pesantren, maka seharusnya pembinaan tidak dilakukan secara insidentil. Program ini harus dilaksanakan secara berkelanjutan. Beberapa santri pondok (4-5 orang) dibina secara intensif tentang kemampuan komputer mereka, baik pengetahuan cara pemanfaatannya dan proses kerja komputer. Disisi lain unit usaha jasa perbaikan komputer ini juga dibuka, sebagai sarana tempat belajar dan magang mereka. Kita / ITS bertindak sebagai fasilitator/mentor yang mendampingi usaha ini sampai mereka benar-benar mandiri dalam pengelolaan unit usaha tersebut.Untuk kelanjutan program tersebut, dibutuhkan komitmen baru antara santri, pemilik pondok pesantren dan tim fasilitator/mentoring.

Meskipun unit usaha jasa service komputer telah didirikan, tetapi dengan mempertimbangkan karakteristik para santri, motivasi dan kemampuan mereka, maka unit usaha ini akan sulit bertahan lama, terutama jika tidak ada komitmen penuh dari pemilik pondok pesantren.

Selain itu, dalam pelatihan ini ada banyak pertanyaan dan permintaan dari beberapa Pondok Pesantren lain yang berada di sekitar lokasi untuk melaksanakan kegiatan serupa di tempat-tempat mereka. Sehingga program ini punya peluang dikembangkan menjadi program: (1) fasilitator/mentoring bagi pengusaha kecil yang bergerak dibidang usaha jasa service komputer; (2) pelatihan prioritas bagi para santri untuk seluruh wilayah Jombang. 


\section{KESIMPULAN DAN SARAN}

Berdasarkan proses dan pelaksanaan kegiatan pengabdian masyarakat yang telah dilakukan di Pondok Pesantren At-Taufiq, maka dapat disimpulkan:

a. Kemampuan santri terhadap pemaham dan pengetahuan komputer sangat kurang, baik dari segi fasilitas (buku, peralatan), maupun motivasi untuk belajar sesuatu yang baru dan teknologi baru.

b. Unit usaha service komputer telah didirikan sebagai salah satu unit usaha koperasi yang ada di lingkungan Pondok Pesantren. Tim menghibahkan seperangkat komputer yang digunakan untuk pelatihan sebagai modal awal.

Berdasarkan animo masyarakat di sekitar kegiatan tersebut, maka disarankan program ini dikembangkan menjadi program: fasilitator/mentoring bagi pengusaha kecil yang bergerak dibidang usaha jasa service komputer; dan pelatihan prioritas bagi para santri untuk seluruh wilayah Jombang. Dengan demikian, diharapkan kemampuan santri atas teknologi yang sudah umum ini, komputer, sama baiknya dengan para pelajar yang bukan santri.

\section{DAFTAR PUSTAKA}

Dhofier, Zamakhsyari, 1985, Tradisi Pesantren: Studi Tentang Pandangan Hidup Kyai, LP3ES, Jakarta.

Hasbullah, 1999, Sejarah Pendidikan Islam di Indonesia:Lintasan Sejarah Pertumbuhan dan Perkembangan, PT Raja Grafindo Persada, Jakarta, (hl 24-27, 138-161).

Hasyim, H. Farid., 1998, Visi Pondok Pesantren Dalam Pengembangan SDM: Studi Kasus di Pondok Pesantren Mahasiswa Al-Hikam, UMM, Program Pasca Sarjana, Tesis.

Prayitno, Irwan, 2008, Revitalisasi Pendidikan Pesantren, http://indonesia.irib.ir

Wahid, Abdurrahman., 2001, Menggerakkan Tradisi: Esai-Esai Pesantren, LkiS, Yogyakarta 